\title{
Terrorism and National Morality
}

\author{
William R. DiPietro ${ }^{1 *}$ \\ ${ }^{1}$ Professor of Economics, Daemen College, Amherst, USA \\ *William R. DiPietro, E-mail: wdipietr@daemen.edu
}

\begin{abstract}
This paper empirically investigates whether there is a negative relationship between the impact of terrorism in a country and national morality. A negative relationship between terrorism and national morality is predicted to exist, because it is reasoned that, in general, greater national morality leads to higher individual and social costs of terrorism, and to lower individual and social benefits from terrorism. Given the standard neoclassical assumption of rationality, an increase in the cost benefit ratio of terrorism due to increased national morality means that, with increased national morality, individuals will rationally choose to engage in less terrorism. The paper uses cross country regression analysis on contemporary data to test these ideas. It regresses the impact of terrorism on national morality and other variables. The results of the empirics of the paper are consistent with the key theoretical hypothesis. They show that the impact of terrorism is negatively associated with national morality.
\end{abstract}

\section{Keywords}

terrorism, sources of terrorism, national morality, cross country regression

\section{Introduction}

Worldwide, terrorism is a major problem, causing extensive property damage and, more importantly, death and injury to innocent victims. Especially since the terrorist incidence on September eleventh at the World Trade Center in the United States, there has been a lot of focus on terrorism, and on the means and ways to deal with terrorism. Terrorism can be defined as the use of force, threat, or intimidation by a group on the population at large in order to achieve political objectives. The hope and desire of both governments and of citizens of countries throughout the world is to diminish the amount of terrorism, and, ultimately, to eliminate it.

A prerequisite for designing policies to effectively bring terrorism under control is to gain greater understanding of the sources of terrorism. Although terrorism is an extremely complicated social phenomenon and likely to entail multiple causes, one potential reason for differences in the amount of terrorism that occurs between countries is differences in national morality. National morality means that citizens in a country are more likely to consider what is ethically correct and right in their decisions and actions. A more moral nation is likely to be subject to less terrorism because moral citizens are less likely themselves to engage in terrorism, and because a more moral nation is more likely to institute 
and to enforce measures to prevent terrorism, and to punish terrorists.

The purpose of this paper is to empirically test, using cross country data, whether there is evidence that national morality reduces terrorism within a country.

The organization of the paper is as follows. Section 2.1 provides a brief literature review. Section 2.2 presents a formal model of terrorism that highlights national morality as a prime source of terrorism. The section that follows gives source information for the variables used in the empirical analysis. Section 2.4 analyzes the results of cross country regressions of terrorism on national morality and on other variables. The final section concludes.

\section{Method}

\subsection{Literature Review}

Abadie investigates the determinants of the risk of terrorism in cross country empirical analysis (Abadie 2004). He finds, in his instrumental variables regressions, that economic variables, such as the log of GDP per capita or the human development index are not significant determinants of country terrorism risk, that while linguistic fractionalization increases the risk of terrorism, ethic fractionalization, or religious fractionalization do not seem to matter, that, three geographic and climatic variables, country area, country elevation, and the fraction of the country in the tropics, each have a positive and significant effect on the risk of country terrorism, and finally, that there appears to exist a nonlinear hump shaped relationship between the risk of terrorism and the lack of political rights. Krieger and Meierrieks summarize the various families of theories explaining terrorism and provide a comprehensive literature review of empirical studies looking at the determinants of terrorism that employ relatively large numbers of countries in their empirical analysis (Krieger \& Meierrieks 2009).

Employing the number of terrorists by country per year as the dependent variable in an equation specification based on a theory in which both terrorists and terrorist leaders maximize utility, Nasir, Ali, and Ur Rehman employ negative binomial regression on a panel consisting of the five South Asian countries of Pakistan, India, Bangladesh, Sri Lanka, and Nepal, for the years 1972 through 2004 to explore potential determinants of terrorism (Nasir, Ali, \& Ur Rehman, 2011). They find that income inequality, inflation, literacy, and an interaction term between literacy and repression, all have positive and significant effects on terrorism, that it is hard to say anything definite about the effect of income per capita on terrorism, that poverty does not seem to matter, and, finally, that terrorism is related to repression in a non-linear hump shaped fashion, suggesting that that greatest amounts of terrorism tend to occur in countries that govern within the intermediate range of repression.

Testas investigates reasons for terrorism in Muslim countries employing a Poisson estimator on a cross country sample of thirty seven Muslim countries (Testas, 2004). He measures terrorism by the average number of yearly terrorist attacks. His empirical evidence suggests that terrorism in Muslim countries is positively related to education and to civil war, and that there is a u-shaped relationship between terrorism and political repression, with increases in political repression at first leading to a reduction in 
terrorism, but, eventually, with further increases, to an increase in terrorism.

Caruso and Schneider use negative binomial regression on a panel of twelve Western European countries for the years 1994 to 2007 in their study of the causes of terrorism (Caruso \& Schneider 2011). For their empirical analysis, they specifically select variables as determinants of terrorism so as to be able to test the validity of three theories of terrorism, economic deprivation, the modernization theory, and the productivity argument. The economic deprivation theory essentially states that economic deprivation is the source of terrorism because more unfavorable economic conditions lead to reduced economic opportunities. Modernization theory maintains that modernization causes terrorism due to the fact that changes brought about by economic development lead to unhappy losing groups. Lastly, the productivity argument proposes that terrorism is positively related to education and the standard of living. In Caruso and Schneider's regressions using the number of terrorist incidents as their dependent variable, they find support for both the deprivation theory and the modernization theory. In addition, they find support for the productivity theory when they use the number of victims per terrorist incident, a measure of terrorist brutality, as their dependent variable.

Choi focuses on the relationship between terrorism and economic growth. He breaks down economic growth into the two components of agricultural sector economic growth and industrial sector economic growth, with the belief that it is industrial economic growth, not agricultural economic growth that is really relevant for terrorism (Choi, 2015). In his empirics, he employs negative binomial regression on a data set consisting of a panel of one hundred twenty seven countries for the years 1970 through 2007. His control variables include income inequality, democracy, state failure, population, and a post-cold war dummy. He runs regressions of overall terrorism, and the three different types of terrorism, domestic terrorism, international terrorism, and suicide terrorism, on overall economic growth, and alternatively, on the two components of economic growth, agricultural sector growth and industrial sector growth.

Choi's empirical findings are consistent with the hard targets theory of terrorism which theorizes that higher economic growth allows governments to provide greater security measures against terrorism (making for harder terrorist targets), which, in turn, causes terrorists to adjust their tactics and the way they undertake terrorism. His results show that while agricultural economic growth is unimportant for overall terrorism and its components, industrial economic growth has a negative and significant effect on overall terrorism, domestic terrorism, and international terrorism, and a positive and significant effect on suicide terrorism. With regard to his control variables, income inequality, and democracy appear to have a positive effect on overall terrorism, domestic terrorism, and international terrorism, but do not appear to be relevant for suicide terrorism, while state failure and population have a positive and significant effect on overall terrorism and each of its three components.

Selecting terrorist determinants on the basis of an opportunity cost theory of terrorism, and using the number of terrorist attacks originating from a country as their dependent variable, Freytag, Kruger, Meierrieks, and Schneider use a mixed effects Poisson regression model on a panel of countries for the 
years 1971 through 2005 (Freytag, Kruger, Meierrieks, \& Schneider, 2009). They run regressions on their entire set of countries, and on four different subgroups of countries, OECD countries, European countries, and two alternative sets of Islamic countries. In general, they find support for the opportunity cost theory of terrorism. In their full sample regression using real GDP per capita as one of the independent variables, they find that lagged terrorism, real GDP per capita, openness, and population, have positive and significant effects on terror, that the ratio investment to GDP, human capital, and economic freedom have a negative and significant effects on terrorism, and, lastly, that the ratio of government consumption to GDP does not appear to be relevant for terrorism.

The present study adds to the literature on the determinants of terrorism, because, to the author's knowledge, although many variables have been considered as sources of terrorism, no one has empirically considered national morality.

\subsection{The Model}

The model consists of the following single equation with its accompanying partial derivative.

$$
\mathrm{T}=\mathrm{f}(\mathrm{M}, \mathbf{C}) \delta \mathrm{E} / \delta \mathrm{O}>0, \delta \mathrm{T} / \delta \mathrm{M}<0
$$

In the equation $\mathrm{T}$ stands for terrorism, $\mathrm{M}$ represents national morality, and $\mathrm{C}$ is a set of control variables.

The essence of the model is that terrorism depends negatively on national morality. Terrorism is theoretically predicted to be negatively related to terrorism for a number of reasons.

First, the chances of an individual becoming a terrorist, the supply of terrorists, is lower in a moral society. To become a terrorist in a moral society with moral upbringings requires an individual to overcome his own moral scruples about performing violent acts, the pronounced opprobrium and negative perceptions in a moral society by people in general and by significant others, and the distinct possibility of menacing and haunting future problems from memory and conscious due to engagement in terrorism. That is to say, the existence of more moral individuals in a more moral society makes it more costly on an individual and personal basis to become a terrorist.

Second, the difficulty of undertaking terrorist acts, of engaging in terrorism, is likely to be greater within a nation that has higher national morality because a more moral society is more morally shocked by terrorism leading to the institution of greater anti-terrorist and terrorist prevention measures. Thus, in more moral societies, the cost of engaging in terrorist acts is apt to be higher.

Third, the consequences of engaging in terrorism are apt to be greater in more moral society. Both the chances of being caught from undertaking terrorist acts, and the sentencing if caught are likely to be greater in a more moral society.

Fourth, a nation with greater national morality is more prone to see, to notice, and to address social problems existing in society such as poverty. To the extent that economic deprivation is a potential cause of terrorism, better social and economic conditions that issue from a more moral society lessen terrorism.

Besides terrorism, other variables, of course, are sure to matter for terrorism. Four other potential 
determinants of terrorism are considered in the paper as control variables. They are militarization, population, trade openness, and democracy. While militarization has rarely, if ever, been considered as a determinant of terrorism, the other three variables have often been considered in the empirical analysis of terrorism.

Just like national morality, militarization, can be considered as another national character variable, but at the opposite end of the spectrum from national morality. Greater militarization by a country is expected to lead to higher levels of terrorism in a country. Besides the fact that increased militarization in a country means that less of a country's scarce resources, as they are more and more drained for military purposes, are devoted to social welfare needs, thereby enhancing the likelihood of terrorism due to economic deprivation, militarization brings about and establishes a force or power consciousness in society with a predisposition to use violence as the preferred means to achieve any and all desired ends. That is to say, in addition to giving the country greater ability to use force, greater militarization is likely to lead people within the country to become more militant in character with a greater willingness and propensity to use force in any and all circumstances. Hence with higher militarization individuals are more habituated and conditioned to use violence, including violence in the form of terrorism, as a solution to problems, rather than employing non-violent alternatives such as compromise and the use of the political process.

The second control variable considered in the study is the population of a country. Terrorism is predicted to be positively related to the country population, as it is assumed that a large population makes it easier for terrorists to hide (more difficult for the authorizes to find) since they can more readily melt into the population.

The third control variable is trade openness. Greater trade openness is predicted to reduce terrorism. It is simply assumed that greater trade, in line with classical trade theory, leads to a higher standard of living, which, in turn, lowers terrorism.

The final control variable is democracy. It is anticipated that terrorism is negatively related to democracy. Democracy allows for greater pluralism and inclusiveness, providing divergent groups in society with access to participation in the political process, with means of expression, and with the possibility of influencing political decisions, thereby giving these groups a viable alternative to violence for obtaining political objectives.

\subsection{Sources for Variables in the Empirical Analysis}

The measure of terrorism is the terrorism index for 2013 of the Institute for Economics and Peace (Institute for Economics and Peace 2015). The Institute of Economics and Peace's terrorism index is designed to gauge the impact of terrorism within a county. The index represents a five year average of terrorism that takes into account the number of terrorist incidents, the number of deaths and casualties caused by terrorism, and the amount of property damage resulting from terrorism. The index varies from zero to ten with the highest value of ten representing the largest impact of terrorism. The index is available for one hundred and sixty two countries. 
The 2013 Crabtree's index of morality, conscience, and the good life (Crabtree, 2013) is employed as a gauge of national moral character (Crabtree, 2013). The Crabtree index considers eighteen different criteria in its construction, and ranges in value from a low of 27.4 to a high of 90.7 for 2013.

Militarization is quantified using the Bonn International Center for Conversion's global militarization index score for 2013 (Bonn International Center for Conversion, 2015). The global militarization index takes into account two military expenditure indicators (the percentage of military expenditures to GDP, military expenditures to health spending), three military personnel indicators (military and paramilitary personnel to the population, military reservists to population, and military and paramilitary personnel to physicians), and one weapons indicator (heavy weapons to population) in its construction. The potential range of the global militarization index is from zero to a thousand.

Population comes from the World Bank, and is in numbers of people for the year 2010 (World Bank, 2014).

The extent of trade openness of a country is captured by using the percentage of total trade (exports plus imports) to GDP for the year 2010. As with the population data, the data for trade openness comes from the World Bank.

Finally, the extent of democracy is measured by using the 2010 democracy index from the Economist Intelligence Unit of The Economist magazine (The Economist, 2010). The index has a potential range in value from one to ten with higher numbers representing a higher country democracy score.

\subsection{The Empircial Findings}

Table 1 shows the outcomes from regressions of terrorism on national morality and on the various control variables.

Table 1. Cross Country Regressions of Terrorism on National Morality and on Other Variables

\begin{tabular}{|c|c|c|c|c|c|}
\hline & (1) & (2) & (3) & (4) & (5) \\
\hline CONSTANT & $\begin{array}{l}5.823 \\
(7.48) \\
*\end{array}$ & $\begin{array}{l}3.291 \\
(2.93)\end{array}$ & $\begin{array}{l}2.846 \\
(2.63)\end{array}$ & $\begin{array}{l}3.463 \\
(3.24) \\
*\end{array}$ & $\begin{array}{l}2.868 \\
(2.71)\end{array}$ \\
\hline MORALITY & $\begin{array}{l}-.0626 \\
(-4.84) \\
*\end{array}$ & $\begin{array}{l}-.0770 \\
(-5.83) \\
*\end{array}$ & $\begin{array}{l}-.0711 \\
(-5.58) \\
*\end{array}$ & $\begin{array}{l}-.0611 \\
(-4.86) \\
*\end{array}$ & $\begin{array}{l}-.0996 \\
(-4.54) \\
*\end{array}$ \\
\hline MILITARIZATION & & $\begin{array}{l}.0061 \\
(3.56) \\
*\end{array}$ & $\begin{array}{l}.0059 \\
(3.60) \\
*\end{array}$ & $\begin{array}{l}.0058 \\
(3.41) \\
*\end{array}$ & $\begin{array}{l}.0071 \\
(4.18) \\
*\end{array}$ \\
\hline POPULATION & & & $\begin{array}{l}4.43 \mathrm{E}-09 \\
(3.68) \\
*\end{array}$ & $\begin{array}{l}\text { 1.17E-09 } \\
(3.31) \\
*\end{array}$ & $\begin{array}{l}3.63 \mathrm{E}-09 \\
(3.14) \\
*\end{array}$ \\
\hline OPENNESS & & & & $\begin{array}{l}-.0133 \\
(-3.01) \\
*\end{array}$ & $\begin{array}{l}-.0115 \\
(-2.64) \\
*\end{array}$ \\
\hline DEMOCRACY & & & & & $\begin{array}{l}.3387 \\
(2.29) \\
* *\end{array}$ \\
\hline RSQ & .134 & .220 & .291 & .329 & .354 \\
\hline $\mathrm{N}$ & 154 & 141 & 141 & 136 & 134 \\
\hline
\end{tabular}


The table consists of five different regression equations. The first is the regression of terrorism on national morality alone without adjusting for any of the control variables. The remaining four equations cumulatively add control variables to the first equation, with militarization added in the second equation, population in the third equation, trade openness in the fourth equation, and democracy in the fifth equation.

The table is set up with the five regression equations that it contains numbered in the first row, and with the r-squared values for these regressions, and the number of countries entering an equation shown in the last two rows. The potential explanatory variables that can enter the equations, national morality and the other control variables, can be found in the first column of the table. If a variable enters an equation, then its estimated coefficient value is given in the appropriate row and column of the table. The numbers in parenthesis under the estimated coefficients are the individual t-statistics. Variables that are significant at the one percent level of significance or better in an equation are identified by a single asterisk under their t-statistic, while those significant at the five percent level of significance appear with two asterisks.

The results provide strong support for the central hypothesis of the paper that national morality matters for terrorism. Looking at the first equation, in which national morality is the sole explanatory variable, shows that national morality on its accounts for over thirteen percent of the cross country variation of the impact of terrorism in countries. National morality is significant at the one percent level of significance in each and every one of the five equations in the table, and, just as theoretically expected, its estimated coefficient is always negative, indicating that higher levels of national morality reduce country terrorism.

The other variable with strong implications for character formation, militarization, behaves just as well as national morality. Right in line with the notion that greater militarization makes people become more militant in character, to think more militant, and to act more militant, including the engaging in more terrorist activity, militarization is positive and significant at the one percent level of significance or better in the four equations in which it appears (equations (2)-(5)).

Two of the three remaining control variables, population and trade openness, also perform quite nicely. Population is positive and significant at the one percent level in the three equations that it enters. This is consistent with the theoretical notion that larger population, by making it more difficult to find and track down terrorists, reduces the cost of terrorism and, as a result, increases terrorism. Trade openness is negative and significant at the one percent level of significance in the two equations that it appears (equations (4) \& (5)).

Democracy, the last control variable, is significant at the five percent level of significance in the single equation in which it appears (equation (5)). However, contrary to the theoretical expectations of the paper, its sign is not positive, but negative. Perhaps, the greater societal openness that accompanies a more liberal and democratic society creates an environment that is easier for the conduct of terrorist operations, and this overcomes other aspects of democracy diminishing terrorism. Alternatively, it may 
be, as others have suggested, the relationship between terrorism and democracy is nonlinear.

\section{Result}

The regression analysis of the paper strongly indicates that terrorism is negatively related to national morality. Whether national morality is used alone as the only explanatory variable in regressions with terrorism as the dependent variable, or when controlling for other variables, the estimated coefficient on national morality is negative and highly significant. In addition, of almost equal importance, militarization also looks to be very relevant for terrorism, with the empirical evidence suggesting that greater militarization leads to higher levels of terrorism.

From these findings, it would seem that a promising way to reduce terrorism in a country is by focusing on national character. If a country is interested in lowering terrorism, then it needs to define the national character in a way that is associated with low levels of terrorism. Two components of a national character with small terrorist predispositions are a national character that has high levels of morality and low levels of militancy.

Of course, once a low terrorism propensity national character is defined and proscribed as the ideal national character, the country needs to make policy and take measures so that individuals in the country internalize this national character and desire to attain it. The society also needs to be wary of allocations of resources, such as high levels of militarization, which are incompatible, and almost sure to undermine, a low terrorism prone national character. In addition, they must be concerned with educational and media content. Content that promotes violence as the only, or the preferred, means to achieve goals must be minimized and discredited.

\section{References}

Abadie, A. (2004). Poverty, Political Freedom, and the Roots of Terrorism. NBER, working paper 10859, Retrieved May 7, 2015, from http://core.ac.uk/download/pdf/6708194.pdf

Basuchoudhary, A., \& Shughar, W. F. (2007). On ethnic conflict and the Origins of Terrorism. Mimeo, University of Mississippi. Retrieved May 15, 2015, from http://www.google.com/url?sa=t\&rct=j\&q=\&esrc=s\&source=web\&cd=1\&ved=0CCIQFjAA\&url $=\mathrm{http} \% 3 \mathrm{~A} \% 2 \mathrm{~F} \% 2 \mathrm{Fforum}$.allaboutcircuits.com $\% 2 \mathrm{Fattachments} \% 2 \mathrm{Fethnic}-\mathrm{conflict}$-and-the-originof-terrorism-pdf.45426\%2F\&ei=3OIVVdTcLILQtQWN0ICoBg\&usg=AFQjCNGkmfff-AvIiVS9r RsVlcrngP89mg\&bvm=bv.93564037,d.b2w

Bonn International Center for Conversion. (2015). Global Militarization Index for 2013. Retrieved April 20, 2015, from http://gmi.bicc.de/index.php?page=ranking-table

Caruso, R., \& Schneider, F. (2011). The Socio-Economic Determinants of Terrorism and Political Violence in Western Europe (1994-2007). European Journal of Political Economy, 27(1), S37-S49. $\begin{array}{llll}\text { Retrieved } & \text { May } & \text { 2015, } & \text { from }\end{array}$ http://www.econ.jku.at/members/Schneider/files/publications/LatestResearch2010/Determinantsof 
Terr_caruso_0709.pdf

Choi, S. W. (2015). Economic Growth and Terrorism: Domestic, International, and Suicide. Oxford Economic Papers, 67(1), 157-181.

Crabtreen, V. (2013). What is the Best Country in the World? An index of Morality, Conscience, and Good Life. Retrieved July 25, 2014, from http://www.vexen.co.uk/countries/best.html

Freytag, A., Kruger, J., Meierrieks, D., \& Schneider, F. G. (2009). The Origins of Terrorism Cross-Country Estimates on Socio-Economic Determinants of Terrorism. Retrieved May 7, 2015, from http://www.econstor.eu/bitstream/10419/31767/1/593202562.PDF

Institute for Economics and Peace. (2015). Vision of Humanity Website. Global Terrorism Index. Retrieved March 19, 2015, from http://www.visionofhumanity.org/\#/page/indexes/terrorism-index

Krieger, T., \& Meierrieks, D. (2009). What Causes terrorism? Retrieved May 7, 2015, from https://www.researchgate.net/profile/Daniel_Meierrieks/publication/5224314_What_causes_terror ism/links/02e7e52488fcfe6874000000.pdf

Nasir, M., Ali, A., \& Rehman, F. R. (2011). Determinants of Terrorism: A Panel Data Analysis of Selected South Asian Countries. The Singapore Economic Review, 56(2), 175-187.

Testas, A. (2004). Determinants of Terrorism in the Muslim World: An Empirical Cross-Sectional Analysis. Terrorism and Political Violence, 16(2), 253-273.

The Economist. (2010). Economist Intelligence Unit, Democracy index 2010. Retrieved August 21, 2014, from http://graphics.eiu.com/PDF/Democracy_Index_2010_web.pdf

World Bank. (2014). World Development Indicators. Retrieved May 20, 2014, from http://databank.worldbank.org/data/views/variableSelection/selectvariables.aspx?source=world-de velopment-indicators 